\title{
Bone marrow stromal cells-derived exosomes target DAB2IP to induce microglial cell autophagy, a new strategy for neural stem cell transplantation in brain injury
}

\author{
FENG-YING YUAN ${ }^{1,2}$, MING-XING ZHANG ${ }^{2}$, YI-HUA SHI ${ }^{2}$, MEI-HUI LI ${ }^{3}$, \\ JIA-YUAN OU ${ }^{3}$, WEN-FANG BAI ${ }^{3,4}$ and MING-SHENG ZHANG ${ }^{1,3}$
}

\begin{abstract}
${ }^{1}$ Department of Rehabilitation Medicine, The First Affiliated Hospital, Jinan University, Guangzhou, Guangdong 510632; ${ }^{2}$ Department of Rehabilitation Medicine The First Affiliated Hospital, Guangdong Pharmaceutical University, Guangzhou, Guangdong 510600; ${ }^{3}$ Department of Rehabilitation Medicine, Guangdong Provincial People's Hospital, Guangzhou, Guangdong 510120; ${ }^{4}$ Academy of Medical Sciences, Guangdong Provincial Institute of Geriatrics, Guangzhou, Guangdong 510080, P.R. China
\end{abstract}

Received October 15, 2019; Accepted May 13, 2020

DOI: $10.3892 /$ etm.2020.9008

\begin{abstract}
Bone marrow stromal cells (MSCs) are a useful source of stem cells for the treatment of various brain injury diseases due to their abundant supply and fewer ethical problems compared with transplant treatment. However, the clinical application of MSCs is limited due to allograft rejection and immunosuppression in the process of MSCs transplantation. According to previous studies, microglial cell autophagy occurs following co-culture with MSCs. In the present study, exosomes were obtained from MSCs and subsequently characterized using transmission electron microscopy, atomic force microscopy and dynamic light scattering particle size analysis. The type of microRNAs (miRs) found in the exosomes was then analyzed via gene chip. The results demonstrated that microglial cell autophagy could be induced by exosomes. This mechanism was therefore investigated further via reverse transcription-quantitative PCR, western blotting and luciferase assays. These results demonstrated that exosomes from MSCs could induce microglial cell autophagy through the miR-32-mediated regulation of disabled homolog 2-interacting protein, thus providing a theoretical basis for the clinical application of miRs in MSCs.
\end{abstract}

Correspondence to: Professor Wen-Fang Bai or Professor Ming-Sheng Zhang, Department of Rehabilitation Medicine, Guangdong Provincial People's Hospital, 106 Zhongshan 2nd Road, Guangzhou, Guangdong 510120, P.R. China

E-mail: freedombwf1008@126.com

E-mail:mszrch@163.com

Key words: bone marrow-derived neural progenitor cell, microglial cell, exosomes, autophagy, microRNAR-32-3p, disabled homolog 2-interacting protein

\section{Introduction}

Conventional drug therapy cannot activate neurons in the brain (1). To treat neurological diseases such as encephalopathy, the only effective form of treatment is neural stem cell transplantation (1-3). Neural stem cells are undifferentiated pluripotent or committed cells (4), the transplantation of which has been documented as an effective method to repair and replace damaged brain tissue by reconstructing partial loop and function (5). Kochanek et al (6) transplanted neural stem cells into the damaged brain tissue of a Parkinson's disease rat model and demonstrated that tremor symptoms were significantly mitigated, in a manner that may be associated with the production of dopamine in midbrain neural stem cells. In another study, Ogawa et al (7) cultured E14.5 stem cells derived from embryonic spinal cords in vitro, after which histopathological analysis was performed 5 days after transplantation. The results revealed that treated rats had significantly recovered motor function. However, immune reactions induced by neural stem cell application and the resulting rejection continue to be the main challenges obstructing their current clinical application $(8,9)$. Therefore, it is important to understand the mechanism underlying the suppression of immune-related cell activity during neural stem cell transplantation $(10,11)$.

Exosomes serve as important tools for the exchange of biologically active substances between cells (12). Most, if not all, mammalian stem cells release exosomes containing certain characteristics of their source parent cells (13). Exosomes contain cell-specific proteins, lipids and nucleic acids, which act as carriers for signal transduction, information exchange between cells and participate in the development of normal physiological processes and diseases (14). Li et al (15) previously reported that human umbilical cord mesenchymal stem cell exosomes significantly inhibit the ratio of peripheral blood $\mathrm{CD}^{+} \mathrm{CD}^{+} \mathrm{T}$ cells and $\mathrm{CD}^{+} \mathrm{CD}^{+} \mathrm{T}$ cells in normal humans. Exosomes with effective immunosuppressive functions have been demonstrated to provide a novel target 
for immunotherapy in treating tumors and autoimmune diseases $(16,17)$.

Previous studies have suggested that autophagy participates in the regulation of inflammation to prevent the development of autoimmune and inflammatory diseases (18). Autophagy not only eliminates macromolecules in autophagic cells, but also clears damaged organelles to maintain intracellular homeostasis (19). Microglia are an important type of neuroimmune cell, which in their activated state, induce tissue repair and neuroprotection by releasing neurotrophic factors and phagocytizing damaged nerve cells (20). In cases of acute trauma to the central nervous system, including traumatic brain/spinal injury, hypoxia or ischemic brain damage, microglia rapidly initiate an immune response (21). Appropriate activation of microglia is beneficial for wound repair and microenvironmental reconstruction, which serves an important role in a number of nerve cell repair processes (22). The occurrence of autophagy in microglia also serves an important role in the differentiation, survival and homeostasis maintenance of transplanted stem cells (23). A study by Wang et al indicated that bone marrow-derived neural progenitor cells can differentiate into neurons, the transplantation of which in vivo can effectively promote motor function in rats following brain injury (24).

In previous studies, bone marrow-derived neural progenitor cells have been characterized, revealing that these cells have the potential to differentiate into neurons (25-27). However, progress has been slow regarding investigation into the treatment of brain injury using neural stem cell transplantation, which may be due to changes in the intracranial microenvironment following brain injury (26). A series of studies have reported that the autophagy of microglia serves an important role in brain injury, involving cranial nerve inflammation, cerebral ischemia and cerebral hypoxia (28-30). Stem cells that are transplanted into the body frequently fail and do not result in tissue repair (31). This may be due to the fact that stem cell transplantation is an exogenous procedure. Whether this process activates microglia autophagy, or whether microglia autophagy is associated with this process is yet to be fully elucidated. Observation and study on this series of problems are therefore urgently required for future clinical work on cell transplantation. To expand on previous studies assessing bone marrow-derived neural progenitor cell-mediated tissue repair $(28-30,32)$, the present study systematically characterized the structure and size of bone marrow-derived neural progenitor exosomes using optical technology, analyzed its content using second-generation sequencing technology and investigated the molecular mechanism underlying microglia autophagy induced by the exosomes from bone marrow-derived neural progenitor cells using molecular and cell biology techniques. The present study provided theoretical information on neural progenitor cell survival and differentiation following the transplantation of bone marrow-derived neural progenitor cells, in addition to offering mechanistic and experimental support for the future clinical application of cell transplantation.

\section{Materials and methods}

Materials. All reagents and chemicals were purchased and used directly without further purification. The bone marrow stromal cell line was collected from the rat model of our team (28-30), whilst the BV-2 microglial cell line was provided by CHI Scientific Inc. (cat. no. 7-1502). All aqueous solutions were prepared in deionized water and triple distilled water was used for all in vitro procedures. MTT, pancreatin and trypsin were purchased from Sigma-Aldrich; Merck KGaA. DMEM/F12 and FBS were purchased from Thermo Fisher Scientific, Inc. and Zhejiang Tianhang Biological Technology Co., Ltd., respectively. ExoQuick ${ }^{\mathrm{TM}}$ reagent (cat. no. EXOQ5A-1; Guangzhou Ruijing Information Technology Co., Ltd.), bicinchoninic acid (BCA) protein assay kit (cat. no. P0012S; Beyotime Institute of Biotechnology) and Ultrafiltration centrifuge tubes (cat. no. UFC901096) were purchased from Guangzhou Ruijing Information Technology Co., Ltd. Rabbit antibodies for disabled homolog 2-interacting protein (DAB2IP; cat. no. ab87811), Beclin1 (cat. no. ab62557), microtubule-associated protein 1A/1B-1 light chain 3 (LC3; cat. no. ab48394), p62 (cat. no. ab109012), CD81 (cat. no. ab124717), CD9 (cat. no. ab223052) and $\beta$-actin (cat. no. ab179467) were purchased from Abcam. The present study was approved by the Ethics Committee of Guangdong Provincial People's Hospital (approval no. GDREC2018042A).

Isolation and culture of bone marrow-derived neural progenitor cells. The methods and procedures for the isolation, culture and identification of bone marrow-derived neural progenitor cells were performed based on previous studies (25-27). Three Sprague-Dawley rats (sex, male; age, 5 weeks; weight, $115-150 \mathrm{~g}$ ) were housed in a temperature of $18-25^{\circ} \mathrm{C}$ and $30-60 \%$ humidity. Temperature $18-25^{\circ} \mathrm{C}$; humidity, $30-60 \%$. Animals were purchased from the Guangdong Medical Laboratory Animal Center. The rats were sacrificed by cervical dislocation and placed in a beaker containing $75 \%$ alcohol for $10 \mathrm{~min}$. The bilateral femurs and tibias were cut, and the soft tissues were removed. The medullary cavities of the bones were washed with $\alpha$-MEM supplemented with $10 \%$ fetal bovine serum. Centrifugation occurred at $200 \mathrm{xg}$ for $20 \mathrm{~min}$. The cloudy cell layers were plated on attachment plastic tissue culture dishes, and the $\alpha$-MEM containing $10 \%$ FBS was changed 4 days later and renewed every 3 days. The cells were plated to obtain adherent rat bone marrow stromal cells (MSCs), which were harvested when cells reached $60-80 \%$ confluence.

Extraction of exosomes from bone marrow-derived neural progenitor cells. Neural progenitor cells were cultured in a 5\% $\mathrm{CO}_{2}$ incubator at $37^{\circ} \mathrm{C}$. When the confluence reached $70-80 \%$, cells were washed with physiological saline and DMEM/F12 medium was replaced. The medium was changed after $48 \mathrm{~h}$ to collect the cell supernatant, followed by centrifugation $\left(5,000 \mathrm{x} \mathrm{g}\right.$ for $\left.20 \mathrm{~min}, 4^{\circ} \mathrm{C}\right)$ to remove cells or cell debris. The exosomal supernatant $(12 \mathrm{ml})$ was then added to the ultrafiltration centrifuge tube, and another $12 \mathrm{ml}$ of the supernatant was added into another ultrafiltration centrifuge tube and centrifuged at 5,000 x g for $40 \mathrm{~min}\left(4^{\circ} \mathrm{C}\right)$. The supernatant was subsequently transferred to a $1.5 \mathrm{ml}$ sterile, enzyme-free centrifuge tube, which was covered well. ExoQuick Exosome reagent was subsequently added. The tube was turned upside down to ensure adequate mixing and incubated at $4^{\circ} \mathrm{C}$ for $12 \mathrm{~h}$. Subsequently, the mixture was centrifuged at $1,500 \times \mathrm{g}$ for 
$30 \min \left(4^{\circ} \mathrm{C}\right)$, before the supernatant was carefully removed and the remaining mixture was centrifuged $\left(5,000 \mathrm{x} \mathrm{g}, 25^{\circ} \mathrm{C}\right)$ for another $5 \mathrm{~min}$. All the liquid was carefully discarded, leaving only the white portion deposited at the bottom. Finally, $10 \%$ original volume of DEPC water was used to resuspend the pellet and mixed prior to storage at $4^{\circ} \mathrm{C}$ for further use.

Identification of exosomes from bone marrow-derived neural progenitor cells and microRNA (miRNA) sequencing. The morphology of exosomes was observed by transmission electron microscopy. A total of $10 \mu \mathrm{l}$ of the $50 \mu \mathrm{l}$ freshly extracted exosomal suspension was obtained for a hanging drop preparation on a copper mesh for $10 \mathrm{~min}$ and dried using filter paper. Subsequently, $5 \mu \mathrm{l}$ of $2 \%$ phosphotungstic acid negative dye solution was added for $5 \mathrm{~min}$ and washed twice with ultrapure water. Excess water was absorbed with filter paper. The copper mesh was then incubated at room temperature until the sample dried naturally. Samples were then placed into sample boxes for observation under a transmission electron microscope at $20^{\circ} \mathrm{C}$ and $30 \%$ humidity (Hitachi $\mathrm{H}-7650$, Hitachi, Ltd.). Exosomes were fixed with $90 \%$ ethanol at $20^{\circ} \mathrm{C}$ for $10 \mathrm{~min}$. Data were analyzed using DigitalMicrograph 3.9 (Gatan, Inc.).

Exosome morphology was observed using atomic force microscopy (AFM). Freshly extracted exosomal suspension was first diluted with $0.9 \%$ physiological saline. A freshly cleaved mica plate was then fixed onto the surface of a glass slide, where $50 \mu 1$ sample solution was dropped slowly onto to the mica plate and allowed to dry. Finally, the sample was examined at room temperature using a silicon probe in tapping mode (Dimension Edge; Bruker Corporation).

The size and distribution of the freshly prepared exosomes (300 $\mu \mathrm{l})$ were measured using a particle size analyzer (Zetasizer Nano ZS90; Malvern Instruments, Ltd.). The ID50 was obtained and calculated once the cumulative size distribution percentage reaches $50 \%$ of the grain size.

For on-column DNase digestion, exosome sample solution (400 $\mu \mathrm{l}$ ) was added to $400 \mu \mathrm{l} 2 \mathrm{X}$ RNAgents ${ }^{\circledR}$ Denaturing Solution (cat. no. Z5651; Promega Corporation), mixed by vortexing and incubated on ice. An equal volume of phenol/chloroform was added, mixed by vortexing and centrifuged $(5,000 \mathrm{x}$ g for $20 \mathrm{~min})$ at $4^{\circ} \mathrm{C}$. The supernatant was then pipetted into absolute ethanol $(1 \mathrm{ml})$, mixed and transferred to a column for centrifugation $(12,000 \times \mathrm{g}$ for $10 \mathrm{~min})$ at $4^{\circ} \mathrm{C}$. A total of $350 \mu 1$ miRNA wash solution 1 was added, followed by further centrifugation $\left(12,000 \mathrm{x}\right.$ for $5 \mathrm{~min}$ at $\left.4^{\circ} \mathrm{C}\right)$ and the supernatant was discarded. DNase I $(10 \mu \mathrm{l})$ was mixed with $70 \mu$ l RDD buffer (Qiagen $\mathrm{GmbH}$ ) before being transferred to the spin column and placed at room temperature for $15 \mathrm{~min}$. A total of $350 \mu \mathrm{l}$ miRNA wash solution 1 was added before further centrifugation $\left(12,000 \mathrm{xg}\right.$ for $5 \mathrm{~min}$ at $\left.25^{\circ} \mathrm{C}\right)$ to discard the supernatant. Wash solution $2 / 3(500 \mu \mathrm{l})$ was then added to rinse the column twice. The spin column was then placed into a new collection tube, where $100 \mu \mathrm{l}$ pre-warmed elution solution was added to the center of the column, followed by centrifugation $\left(12,000 \times \mathrm{g}\right.$ for $5 \mathrm{~min}$ at $\left.25^{\circ} \mathrm{C}\right)$. The resulting liquid in the collection tube was the extracted total RNA and the sample was stored at $-80^{\circ} \mathrm{C}$.

Total RNA was initially used in a chip experiment, which was subjected to quality inspection using NanoDrop ND-2000 spectrophotometer (Thermo Fisher Scientific, Inc.) and Agilent Bioanalyzer 2100. Qualified RNA was then subjected to subsequent chip experiments. High-throughput analysis of the miRNA expression profiles was performed using Agilent miRNA chip technology (Rat miRNA 8x15k v21.0 microarray; Agilent Technologies $\mathrm{GmbH}$ ). Sinotech Genomics performed miRNA sequencing. The chip results were scanned using the Agilent Microarray Scanner, where the data were read by the Feature Extraction software 10.7.1.1 (Agilent Technologies $\mathrm{GmbH}$ ), followed by normalization using the $\mathrm{R}$ language package.

Bone marrow-derived neural progenitor exosome-induced microglia autophagy. For autophagy detection in BV2 cells, different amounts of exosomes were added to BV2 cells $(5 \mu 1$, $360 \mathrm{ng} / \mu \mathrm{l} ; 15 \mu \mathrm{l}, 360 \mathrm{ng} / \mu \mathrm{l})$ at $37^{\circ} \mathrm{C}$. After $48 \mathrm{~h}$, an inverted fluorescence microscope (TE2000-E; Nikon Corporation) was used to capture images. The culture medium (DMEM/F12) was then removed, cells were washed once with PBS and fixed with $2.5 \%$ glutaraldehyde solution at $4^{\circ} \mathrm{C}$ overnight. The fixative was removed, the sample was rinsed three times with $\mathrm{PBS}$ and fixed with $1 \%$ osmic acid solution for $2 \mathrm{~h}$ at $37^{\circ} \mathrm{C}$. The sample was subsequently dehydrated using an ascending ethanol gradient $(30,50,70,80,90$ and $95 \%)$ and treated with pure acetone for $20 \mathrm{~min}$ at $25^{\circ} \mathrm{C}$. The sample was treated with a mixture of epikote resin and acetone $(\mathrm{v} / \mathrm{v}=1 / 1)$ for $1 \mathrm{~h}$, followed by the same mixture but at a higher concentration of the embedding agent $(\mathrm{v} / \mathrm{v}=3 / 1)$ for $3 \mathrm{~h}$ before incubation with $100 \%$ embedding agent overnight at $25^{\circ} \mathrm{C}$. The treated sample was embedded and heated at $70^{\circ} \mathrm{C}$ overnight to obtain an embedded sample. The samples were sectioned using a Leica EM UC7 ultramicrotome (Leica Microsystems $\mathrm{GmbH}$ ) where 70-90 nm sections were obtained. The sections were stained with $10 \%$ lead citrate solution for $10 \mathrm{~min}$ at $25^{\circ} \mathrm{C}$ and $50 \%$ uranyl acetate for $10 \mathrm{~min}$ at $25^{\circ} \mathrm{C}$ before observation under a transmission electron microscope (Hitachi H-7650, Hitachi, Ltd.).

For colony formation assays, BV cells were seeded into six-well plates at 500 cells/well. Following $24 \mathrm{~h}$ incubation at $37^{\circ} \mathrm{C}$ with $5 \% \mathrm{CO}_{2}$, DMEM was then replaced and exosomes were added for 14 days $(5 \mu \mathrm{l}, 360 \mathrm{ng} / \mu \mathrm{l})$. The control group was not treated with exosomes. The cells were then fixed with $90 \%$ ethanol for $30 \mathrm{~min}$ at $25^{\circ} \mathrm{C}$ and washed with PBS three times. After further incubation for $30 \mathrm{~min}$ at $37^{\circ} \mathrm{C}$ in the dark and staining with $1 \mathrm{X}$ Giemsa solution at $25^{\circ} \mathrm{C}$ for $20 \mathrm{~min}$, images was obtained on an inverted microscope (TE2000-E; Nikon Corporation) at x100 magnification.

MTT assay. Inhibition of cell growth by exosomes was measured using an MTT assay. The cells were exposed to exosomes at different times (12, 24 and 48 h). Briefly, BV cells were seeded in 96 -well tissue culture plates $\left(5 \times 10^{3}\right.$ cells/per well) for $12 \mathrm{~h}$ at $37^{\circ} \mathrm{C}$ with $5 \% \mathrm{CO}_{2}$. After exosome $(5 \mu \mathrm{l}$, $360 \mathrm{ng} / \mu \mathrm{l})$ treatment, BV2 cells were incubated for $24 \mathrm{~h}$ at $37^{\circ} \mathrm{C}$ with $5 \% \mathrm{CO}_{2}$. After incubation, $20 \mu \mathrm{l} /$ well MTT solution $(5.0 \mathrm{mg} / \mathrm{ml}$ in PBS) was added and incubated for $4 \mathrm{~h}$ at $37^{\circ} \mathrm{C}$ with $5 \% \mathrm{CO}_{2}$. The medium was aspirated and replaced with $100 \mu \mathrm{ll} /$ well DMSO to dissolve the formazan salt. The absorbance intensity was measured by using a microplate spectrophotometer at a wavelength of $570 \mathrm{~nm}$ (Thermo Fisher Scientific, Inc.). 
Molecular analysis of autophagy induction. The number of exosomes used for molecular mechanism analysis was determined by measuring the total protein concentration in the exosomes, which was obtained using the BCA kit (360 ng/ $\mu \mathrm{l})$.

Western blotting. The exosomes secreted by the bone marrow-derived neural progenitor cells and the bone marrow-derived neural progenitor cells of the normal control group were first collected by centrifugation at $12,000 \mathrm{x} \mathrm{g}$ for $10 \mathrm{~min}$ at $4^{\circ} \mathrm{C}$. A total of $70 \mu \mathrm{l}$ RIPA buffer (cat. no. P0013C; Beyotime Institute of Biotechnology) was then added and incubated on ice for $30 \mathrm{~min}$. The protein was quantified using the BCA method, following which the protein mass concentration was adjusted to $5 \mathrm{~g} / \mathrm{l}$ using RIPA buffer and stored at $-80^{\circ} \mathrm{C}$ for further use. For electrophoresis, $20 \mu \mathrm{g}$ protein was separated by $10 \%$ SDS-PAGE, before being transferred onto nitrocellulose membranes at $100 \mathrm{~V}$ for $1 \mathrm{~h}$ and blocked in blocking solution (cat. no. P0216; Beyotime Institute of Biotechnology) for $1 \mathrm{~h}$ at $37^{\circ} \mathrm{C}$. The membranes were then incubated with an appropriate amount of primary antibodies against DAB2IP, Beclin1, p62, CD81, CD9 and LC3 (all, 1:1,000) overnight, following which the membranes were incubated with corresponding secondary antibody (alkaline phosphatase-labeled goat anti-rabbit immunoglobulin $\mathrm{G}$; 1:1,000; cat. no. A0239; Beyotime Institute of Biotechnology) for $1 \mathrm{~h}$ at room temperature. The protein bands were visualized by ECL luminescence, following which densitometric analysis was performed. Protein bands were visualized using GelDoc XR (BioRad Laboratories, Inc.).

Calcium ion detection. Different amounts of exosomes were added to BV2 cells (5 $\mu \mathrm{l}, 360 \mathrm{ng} / \mu \mathrm{l} ; 15 \mu \mathrm{l}, 360 \mathrm{ng} / \mu \mathrm{l})$, which were then incubated for $24 \mathrm{~h}$ at $37^{\circ} \mathrm{C}$. Fluo-3 AM working solution (1 $\mu \mathrm{M}$; cat. no. S1056; Beyotime Institute of Biotechnology) was added to sufficiently cover the cells. After incubation for $30 \mathrm{~min}$ at $37^{\circ} \mathrm{C}$, the fluorescence of Fluo-3 was measured (excitation wavelength, $488 \mathrm{~nm}$; emission wavelength, $530 \mathrm{~nm}$ ) using a fluorescence microplate reader (Varioskan Flash; ThermoFisher Scientific, Inc.) to assess any changes in intracellular calcium ion concentrations.

Luciferase assay. The miRNA and 3'-UTR binding site (accession no. NM_032552.3; Homo sapiens DAB2 interacting protein, DAB2IP, transcript variant $1, \mathrm{mRNA}$ ) was predicted by BLAST (https:/docs.microsoft.com/en-us/previous-versions/ hh397746(v=msdn.10)? redirectedfrom=MSDN). Upon reaching a confluence of $\sim 70 \%, 293 \mathrm{~T}$ cells (American Type Culture Collection; incubated at $37^{\circ} \mathrm{C}$ with $5 \% \mathrm{CO}_{2}$ ) were seeded into six-well plates at a density of $2 \times 10^{6}$ cells $/ \mathrm{ml}$ in DMEM. Following incubation at $37^{\circ} \mathrm{C}$ in $5 \% \mathrm{CO}_{2}$ for $16 \mathrm{~h}$, cell confluency typically reached $\sim 80 \%$. The culture medium was then pipetted into each well, where $2 \mathrm{ml}$ Opti-MEM was added to each well, and culture continued in a constant temperature incubator at $37^{\circ} \mathrm{C}$. Plasmids (Guangzhou RiboBio Co., Ltd.; $2 \mu \mathrm{g}$; WT or mut-psi-CHECK2 and scrambled RNA, mimic-miR-32-3P or inhibitor-miR-32-3P; $1: 1$ ratio) was mixed with $0.5 \mathrm{ml}$ Opti-MEM and $5 \mu$ l Lipofectamine ${ }^{\circledR} 2000$ (Invitrogen; Thermo Fisher Scientific, Inc.) diluted in $0.5 \mathrm{ml}$ of opti-MEM.

miR-32 mimic was transfected into $293 \mathrm{~T}$ cells using Lipofectamine (Invitrogen; Thermo Fisher Scientific, Inc.). The sequences of the miRNAs (synthesized by Guangzhou RiboBio Co., Ltd.) were as follows: mimic-miR-32-3p, 5'-CAATTTAGT GTGTGTGATATTT-3'; inhibitor-miR-32-3p, 5'-AAATATCAC ACACACTAAATTG-3' and scramble RNA (reference), 5'-GAT AGACGCGCAGGAAGTAGA-3'. The plasmid mixture and the transfection reagent mixture were then mixed and incubated for $20 \mathrm{~min}$ prior to addition to the cells. Following $6 \mathrm{~h}$ culture at $37^{\circ} \mathrm{C}$, cells were added with $2 \mathrm{ml}$ complete medium and incubated at $37^{\circ} \mathrm{C}$ for a further $24 \mathrm{~h}$. The medium of the six-well plate was then removed, washed twice with PBS and lysed with $1 \mathrm{X}$ PLB. After incubation for $15 \mathrm{~min}$ at room temperature, $20 \mu \mathrm{l}$ lysates was transferred to a 96-well plate, where $100 \mu \mathrm{l}$ Luciferase Assay Reagent II (LAR II) was added to each well. The fluorescence value was detected using a chemiluminescence apparatus. A total of $100 \mu \mathrm{l}$ Stop \& Glo ${ }^{\circledR}$ buffer was added to each well and the fluorescence was measured for a second time. Renilla luciferase activity was used as an internal control.

Reverse transcription-quantitative PCR (RT-qPCR). BV2 cells were seeded in six-well plates $\left(1 \times 10^{6}\right.$ cells/well) for $12 \mathrm{~h}$ at $37^{\circ} \mathrm{C}$, then different amounts of exosomes were added to BV2 cells $(5 / 15 \mu \mathrm{l}, 360 \mathrm{ng} / \mu \mathrm{l})$ for $24 \mathrm{~h}$ at $37^{\circ} \mathrm{C}$. The BV2 cells were collected, total RNA was then extracted using RNAprep Pure Cell/Bacteria kit (cat. no. DP430; Tiangen Biotech Co., Ltd.) in accordance with the manufacturer's protocol, following which RNA purity was measured using a NanoDrop 2000 spectrophotometer (Thermo Fisher Scientific, Inc.). The sequences used were as follows: U6 forward, 5'-CTCGCT TCGGCAGCACA-3' and reverse, 5'-AACGCTTCACGA ATTTGCGT-3'; miR-32-3p, 3'-CAATTTAGTGTGTGTGAT AT-5'; miR-211-3p, 3'-GCAAGGACAGCAAAGGGGGGC-5'; miR-188-5p, 3'-CAT CCC TTGCATGGTGGAGGG-5'; miR-466b-5p, 3'-TGATGTGTGTGTACATGTACAT-5'.

RNA was added with polyA tail and reverse transcribed into cDNA (RevertAid First Strand cDNA synthesis kit; cat. no. K1622; Thermo Fisher Scientific, Inc.), following which the expression of four potential target genes were detected via qPCR (GoTaq qPCR and RT-qPCR Systems; cat. no. A6001; Promega Corporation). Reactions were performed on a fluorescence qPCR instrument (CFX Connect; cat. no. 1855200; BioRad Laboratories, Inc.). The following thermocycling conditions were used for the qPCR: Initial denaturation at $95^{\circ} \mathrm{C}$ for $10 \mathrm{~min}$, followed by 50 cycles of $95^{\circ} \mathrm{C}$ for $15 \mathrm{sec}$ and $60^{\circ} \mathrm{C}$ for $1 \mathrm{~min}$. The relative $\mathrm{mRNA}$ levels of target samples to control samples were calculated according to $2^{-\Delta \Delta \mathrm{Cq}}$ method (33).

Statistical analysis. Data are expressed as the mean \pm standard error of the mean based on at least three independent experiments. Statistical analysis was performed using one-way ANOVA, followed by a Bonferroni post hoc test for multiple group comparisons or a Student's unpaired t-test for pairwise comparisons. $\mathrm{P}<0.05$ was considered to indicate a statistically significant difference unless otherwise indicated. All analyses were performed using GraphPad Prism Software version 6.0 (GraphPad Software, Inc.).

\section{Results}

Isolation of bone marrow-derived neural progenitor cells and the effect in BV2 cells. The methods and procedures for the 
A

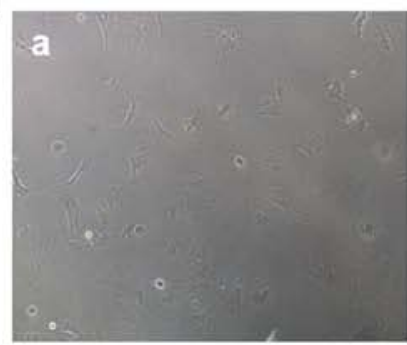

C

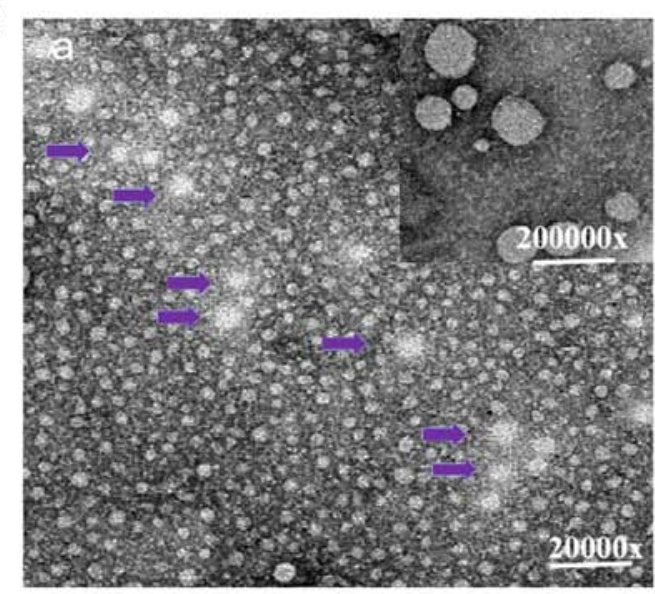

D

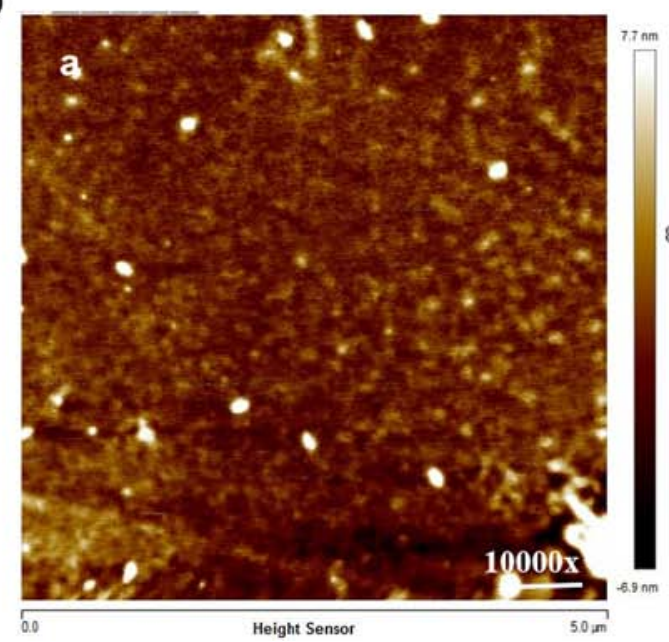

B

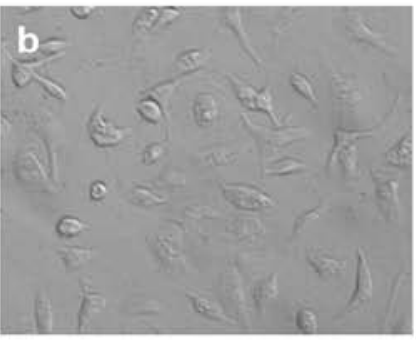

b
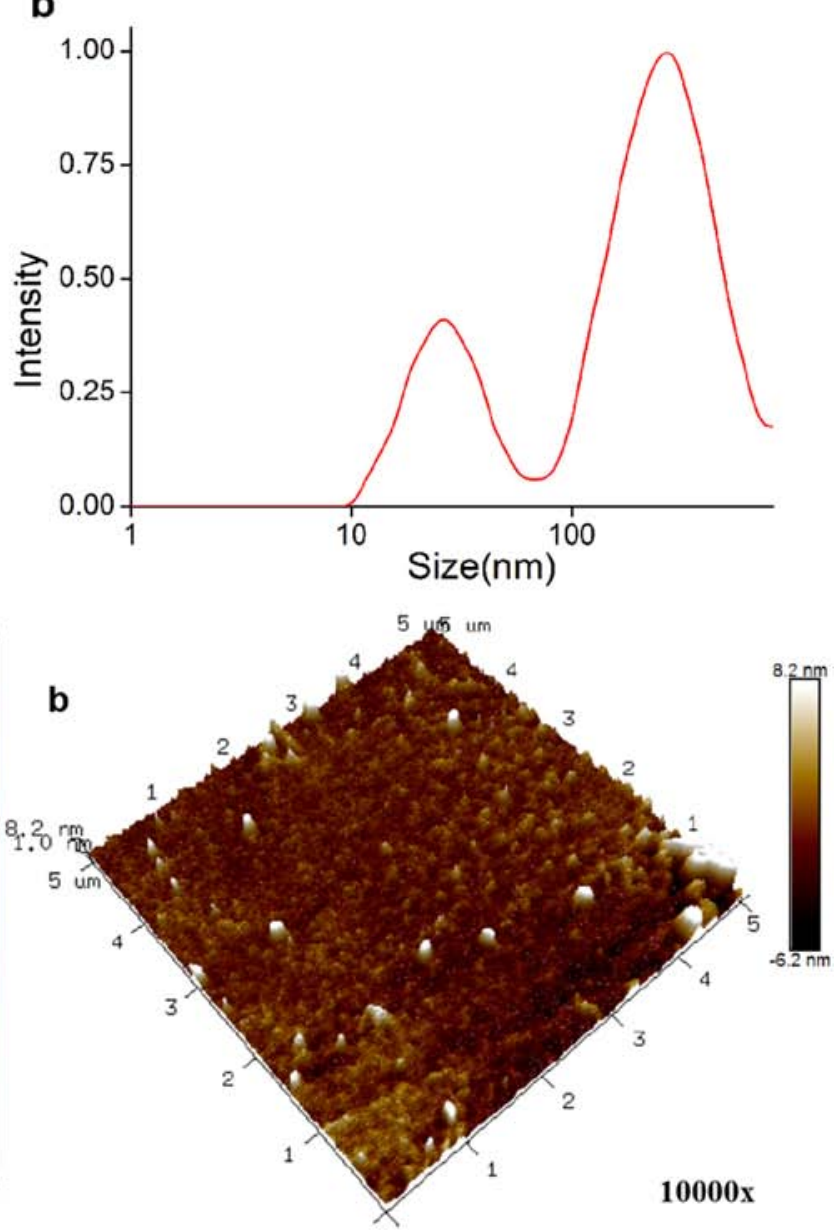

Figure 1. Characterization of bone marrow-derived neural progenitor cells, BV-2 microglial cells and exosomes. Representative images of (Aa) bone marrow-derived neural progenitor cells and (Ab) BV-2 microglial cells. Magnification, x200. (B) The expression of exosome-associated target proteins in bone-marrow derived nerve progenitor cell exosomes. (Ca) Transmission electron microscopy of bone-marrow derived nerve progenitor cell exosomes revealed circular or elliptical, homogeneous vesicles with lipid bilayer membrane structures; $(\mathrm{Cb})$ size distribution of exosomes from bone marrow derived nerve progenitor cells by laser particle analysis. Arrows indicate vesicles with lipid bilayer membranes. (Da) The images of exosomes from bone marrow-derived nerve progenitor cells were obtained using atomic force microscopy. (Db) Three-dimensional topography images obtained using atomic force microscopy (magnification, $\mathrm{x} 10,000)$.

isolation, culture and identification of bone marrow-derived neural progenitor cells were performed based on previous studies (25-27). As shown in Fig. 1A-a, the morphology of the isolated and identified bone marrow-derived neural progenitor cells appeared to be slightly. The mouse microglial cell line BV-2 was purchased and sub-cultured, which were in fusiform states (Fig. 1A-b). Exosome-associated target proteins, such as CD9 and CD81, are types of biomarkers for exosomes (34). As shown in Fig. 1B, the exosomes of bone marrow-derived neural progenitor cells were first characterized via western blotting, by examining the expression of exosome-associated target proteins CD9 and CD81 (13-15).
Morphology and particle size distribution of exosomes from bone marrow-derived neural progenitor cells. The exosomes of bone marrow-derived neural progenitor cells were collected via ultrafiltration concentration centrifugation and observed by transmission electron microscopy (Fig. 1Ca). They were found to be either circular or elliptical in shape, of homogeneous distribution, with double-layered lipid vesicle (arrows). The vesicles secreted by bone marrow-derived neural progenitor cells have clear vesicle membrane structures with higher internal dioptres compared with the background, consistent with the exosome features observed (34). Based on this, the size of exosomes from bone marrow-derived neural progenitor 

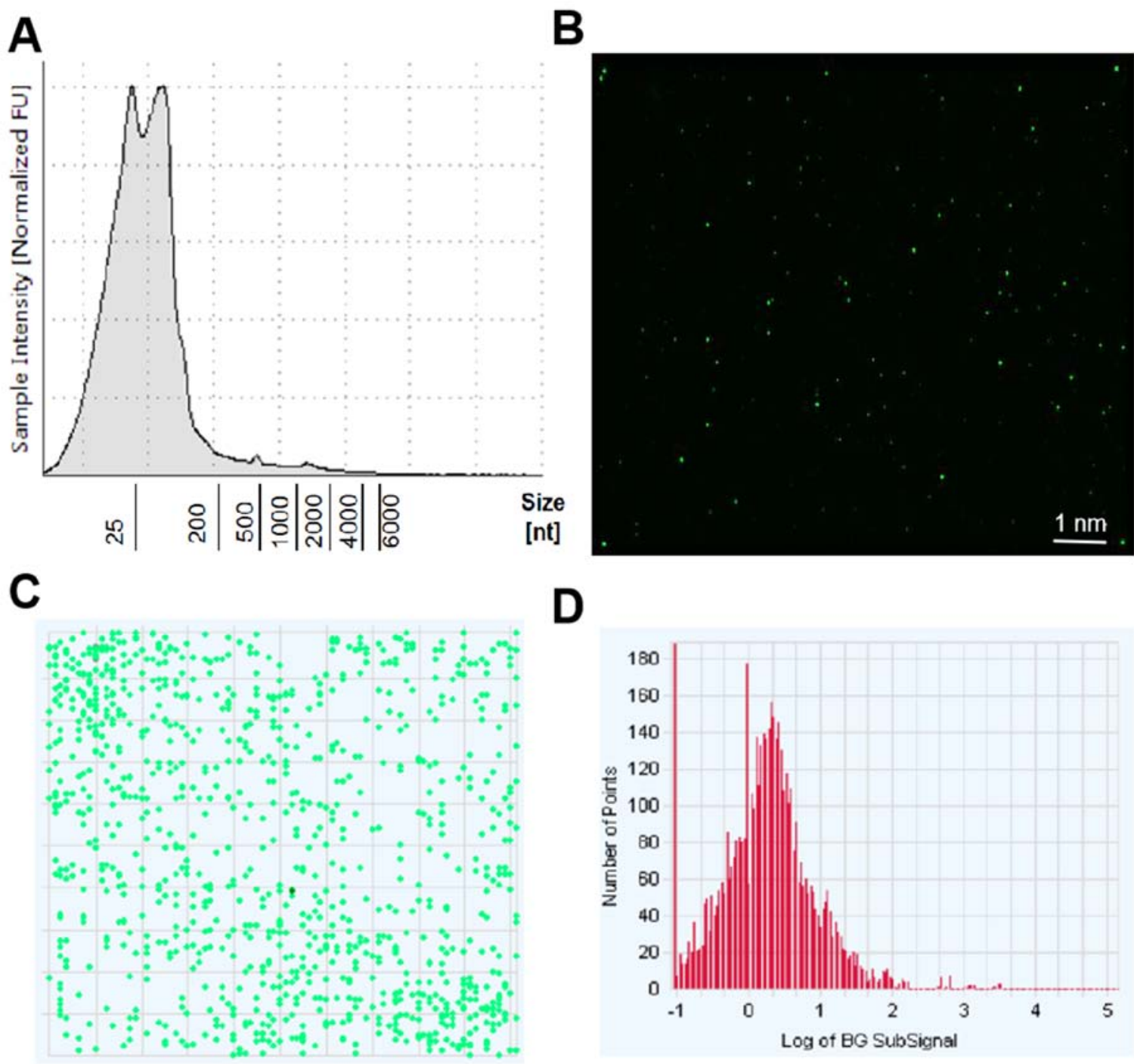

D

Spatial distribution of all outliers on the array

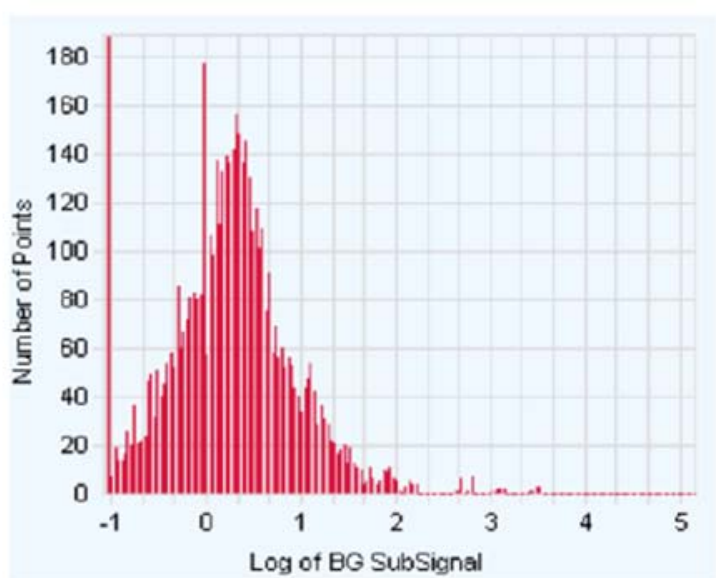

Histogram of signals plot

Figure 2. Sequencing miRNA isolated from exosomes from bone marrow-derived nerve progenitor cells. (A) Quality inspection result of total RNA isolated from the exosomes. (B) The original data obtained from the Agilent miRNA chip. Green dots show miRNAs that were detected. (C) The data of the Agilent miRNA chip normalized to the fluorescent signal point of the chip probe. (D) The fluorescence detection signal of the miRNA chip. miRNA, microRNA. BG, background.

cells was then measured using a laser particle size analyzer. The abscissa represents the diameter range, whilst the ordinate represents the concentration/intensity of the exosomes from the bone marrow-derived neural progenitor cells. The exosome $\mathrm{ID}_{50}$ value of the bone marrow-derived neural progenitor cells was $100 \mathrm{~nm}$ (Fig. 1Cb).

The surface morphology and three-dimensional structures of these exosomes were analyzed further using AFM (Fig. 1D). The average diameter of the exosomes was measured to be $28.63 \pm 11.59 \mathrm{~nm}(\mathrm{n}=3)$, where a small number of vesicles $>1,000 \mathrm{~nm}$ in diameter were observed. The results indicated that the exosomes of bone marrow-derived neural progenitor cells were successfully isolated, where the diameter of most exosomes was $<100 \mathrm{~nm}$.

Sequencing of miRNA found in exosomes from bone marrow-derived neural progenitor cells. The exosomes of bone marrow-derived neural progenitor cells were collected and total exosomal RNA was extracted. High-throughput analysis of miRNA expression profiles was performed using Agilent miRNA chip technology. An increasing number of studies have previously demonstrated that miRNAs serve important roles in various diseases and biological functions $(34,35)$. miRNAs can regulate a number of physiological processes, including proliferation, cell cycle progression, apoptosis, invasion and angiogenesis by inhibiting the expression of target genes (36). The results of sequencing of miRNA shown that 758 miRNAs found in the exosomes met the quality control requirements of bone marrow-derived neural progenitor cells. The original data of chip-based detection is presented in Fig. 2B. The obtained data is demonstrated in Fig. 2C. The signal value of the original data miRNA probe is presented in Fig. 2D.

From the 758 miRNAs detected in the exosomes of bone marrow-derived neural progenitor cells, the top 20 miRNAs according to abundance were selected. Information, including type name, the degree of correspondence between the probe 
Table I. Results and information of miRNA chip detection in exosomes (top 20).

\begin{tabular}{|c|c|c|c|}
\hline Systematic name & $\begin{array}{l}\text { Total probe signal } \\
\text { (raw) data }\end{array}$ & $\begin{array}{l}\text { Total probe signal } \\
\text { (normalized) }\end{array}$ & Sequence \\
\hline $\operatorname{miR}-1224$ & 1511.147 & 10.561428 & 5'-GTGAGGACTCGGGAGGTGG-3' \\
\hline miR-466b-5p & 737.30896 & 9.526125 & 5'-TATGTGTGTGTGTATGTCCATG-3' \\
\hline $\operatorname{miR}-32-3 p$ & 129.2438 & 7.0139513 & 5'-CAATTTAGTGTGTGTGATATTT-3' \\
\hline miR-1896 & 82.5686 & 6.3675213 & 5'-TGGTGGGTGAGGAGGAGG-3' \\
\hline miR-672-5p & 73.4067 & 6.1978397 & 5'-TGAGGTTGGTGTACTGTGTGTGA-3' \\
\hline miR-1306-3p & 64.6163 & 6.013826 & 5'-ACGTTGGCTCTGGTGGTG-3' \\
\hline $\operatorname{miR}-211-3 p$ & 34.9854 & 5.128681 & 5'-GCAGGGACAGCAAAGGGGTGC-3' \\
\hline $\operatorname{miR}-466 c-5 p$ & 33.4107 & 5.0622387 & 5'-TGTGATGTGTGTATGTACATG-3' \\
\hline miR-466d & 31.84107 & 4.992817 & 5'-ATGTGTGTGTATGTCCTTTTGT-3' \\
\hline miR-465-5p & 31.7184 & 4.987248 & 5'-TATTTAGAACGGTGCTGGTGTG-3' \\
\hline $\operatorname{miR}-3473$ & 31.4372 & 4.9744005 & 5'-TCTAGGGCTGGAGAGATGGCTA-3' \\
\hline miR-3593-3p & 27.8128 & 4.797677 & $\begin{array}{l}\text { 5'-CCATCACCACACGACTGGATTTTGG } \\
\text { CCTCCGCAGGGTTGAAGCTGCTAGAGA } \\
\text { AGCTTCAACCTTAAGGGGGCCTCAGGG } \\
\text { AGAGAGGAGTGG-3' }\end{array}$ \\
\hline $\operatorname{miR}-1249$ & 26.360802 & 4.720322 & $\begin{array}{l}\text { 5'-GGGAGGAGGGAGGAGATGGGCCAAGT } \\
\text { TCCCTCTGGCTGGAACGCCCTTCCCCCC } \\
\text { CTTCTTCACCTG-3' }\end{array}$ \\
\hline miR-6216 & 25.43394 & 4.668683 & 5'-GATACACAGAGGCAGGAGGAGAA-3' \\
\hline $\operatorname{miR}-3588$ & 25.288 & 4.660381 & 5'-TCACAAGTTAGGGTCTCAGGGA-3' \\
\hline miR-483-5p & 24.348429 & 4.6057568 & 5'-AAGACGGGAGGAAAGAAGGGAG-3' \\
\hline $\operatorname{miR}-2985$ & 23.6542 & 4.5640244 & $\begin{array}{l}\text { 5'-ATCGCCACACCTAAAGGATCCTCATTA } \\
\text { AGGTGGGTGGAATAGTATAACAATGTGCT } \\
\text { CAATGTTGTTATAGTATCCCACCTACCCTG } \\
\text { ATGTGTCTTTAAGACTCTAACGGT-3' }\end{array}$ \\
\hline miR-296-5p & 20.11955 & 4.3305264 & 5'-AGGGCCCCCCCTCAATCCTGT-3' \\
\hline miR-188-5p & 19.535389 & 4.2880177 & 5'-CATCCCTTGCATGGTGGAGGG-3' \\
\hline miR-3562 & 18.44011 & 4.2047753 & 5'-TTGGGGCAGTGGCTGGATGGGA-3' \\
\hline
\end{tabular}

miR, microRNA.

and the original data, in addition to their active sequence structure information, are provided in Table I. After combining literature reports (37-41), four potential miRNAs which have been documented to serve a role in exosome-induced microglia autophagy were identified: rno-miR-32-3p, rno-miR-211-3p, rno-miR-188-5p and rno-miR-465-5p. RT-qPCR was performed to investigate the differences in the relative expression of these four potential target miRNAs in the microglia cells in the presence or absence of bone marrow-derived neural progenitor exosomes (Fig. 3).

It was revealed that that miR-32-3p exhibited the highest expression, which meant it could be used as a potential target molecule (Fig. 3A). Therefore, the expression of miR-32-3p in microglia was examined further using different volumes of exosomes and different treatment times, the results of which are presented in Fig. 3B.

Bone marrow-derived neural progenitor exosomes induce microglia autophagy. Using molecular biology and cell biology techniques, the mechanism underlying microglia autophagy induced by exosomes from bone marrow-derived neural progenitor cells was investigated further. MTT and colony formation assays were performed to investigate the effects of exosomes from bone marrow-derived neural progenitor cells on the viability and proliferation of microglia. Exosomes of bone marrow-derived neural progenitor cells were collected during microglia growth (Fig. 4A). High-dose exosomes (Ex-H) had no effect on the growth of microglia. No statistically significant differences were observed in the survival rates between cells cultured for $12 \mathrm{~h}$ with exosomes and cells without the addition of exosomes, nor between cells cultured in the absence of exosome treatment and those treated with exosomes for 24 and $48 \mathrm{~h}$.

This suggested that exosomes of bone marrow-derived neural progenitor cells had no significant effect on microglia cell growth. This can be clinically relevant if performed without affecting the growth of normal cells. By measuring the formation rate of colonies, the effect of exosomes from bone marrow-derived neural progenitor cells on the proliferation of microglia was investigated (Fig. 4B). The number of microglial 


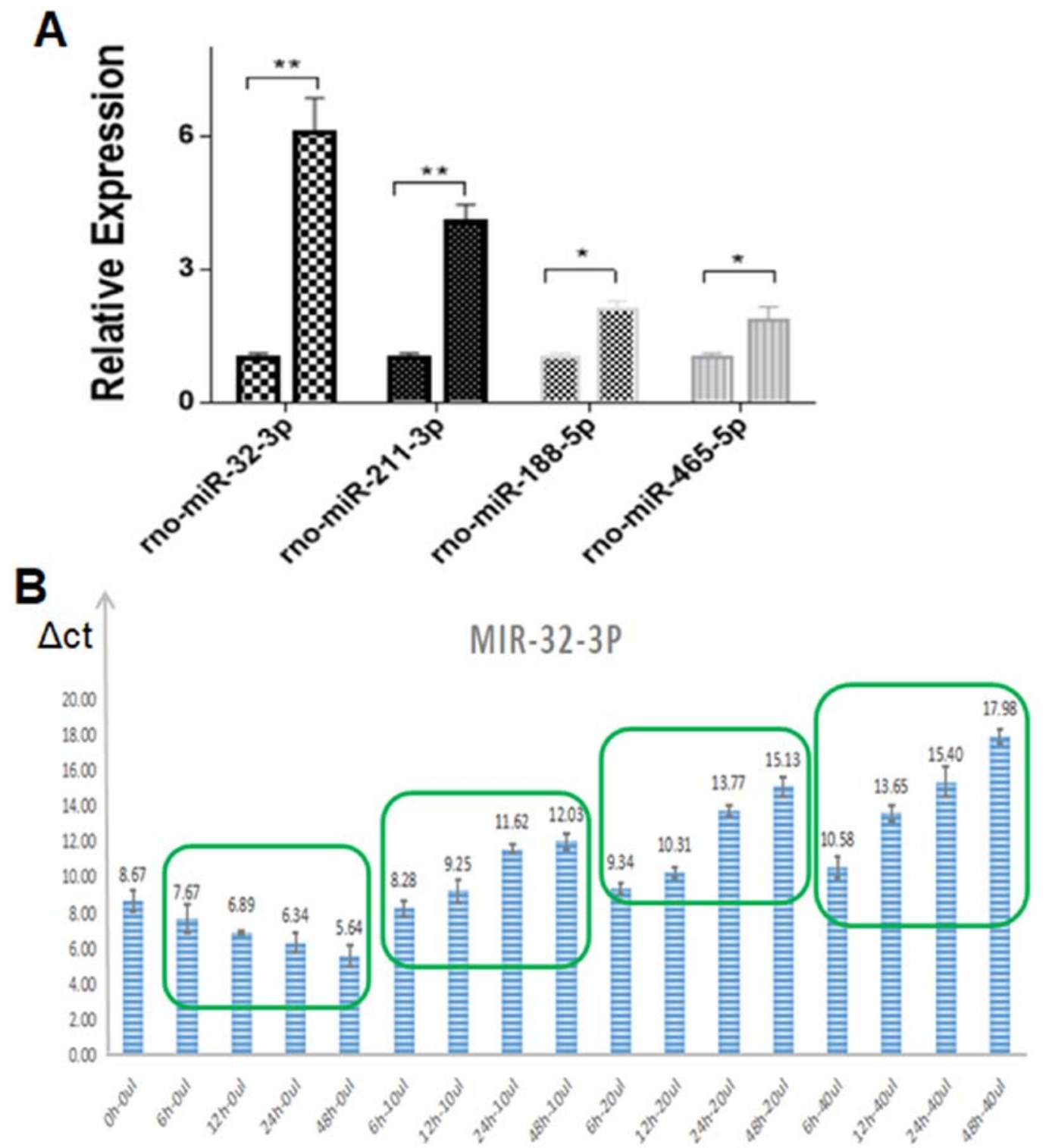

Figure 3. miRNA expression on the exosomes of bone marrow-derived neural progenitor cells. (A) Relative expression of potential target miRNAs in the BV-2 microglial cell line before and after exosome treatment $(5 \mu \mathrm{l})$. (B) The expression of miR-32-3p in the BV-2 microglial cell line before and after treatment with different volumes of exosome over time is presented. ${ }^{*} \mathrm{P}<0.05$ and ${ }^{* *} \mathrm{P}<0.01$. miRNA/miR, microRNA.

colonies formed following the addition of exosomes from bone marrow-derived neural progenitor cells was not found to be markedly different from the control group, suggesting that the addition of exosomes from bone marrow-derived neural progenitor cells did not affect microglia proliferation.

Notably, the shape of microglial cells change from roundness to fusiform after the addition of exosomes from bone marrow-derived neural progenitors (Fig. 4C). Damaged organelles such as swollen and degenerated mitochondria were observed under a transmission electron microscope (Fig. 4D). Additionally, residue that could not be fully degraded in the autolysosome was observed. These results suggested that exosomes from bone marrow-derived neural progenitor cells induced microglia autophagy without affecting growth and proliferation.

Western blotting and luciferase reporter gene assays were subsequently performed to validate the potential targets of
miR-32-3p and associated regulatory mechanism. Following the addition of exosomes from bone marrow-derived neural progenitor cells, the expression of the DAB2IP protein in microglial cells was found to be upregulated whilst that of p62 was significantly downregulated (Fig. 5A). The shear band (the upper or lower band LC3 II/LC3 I) of the LC3 protein was also found to be significantly increased. In addition, Beclin 1 was observed to be significantly upregulated following the addition of exosomes from bone marrow-derived neural progenitor cells (Fig. 5A). Different amounts of exosomes were added to BV2 cells [Low dose (Ex-L), $5 \mu 1,360 \mathrm{ng} / \mu 1$; high-dose (Ex-H), $15 \mu \mathrm{l}, 360 \mathrm{ng} / \mu \mathrm{l}]$, and the expression of proteins CD9 and CD81 of Ex-H was markedly higher compared with Ex-L (Fig. 1B). These results suggested that microglia autophagy may be associated with the target binding of miR-32-3p and the DAR2IP (39), alongside the subsequent activation of Beclin1 (42). 
A

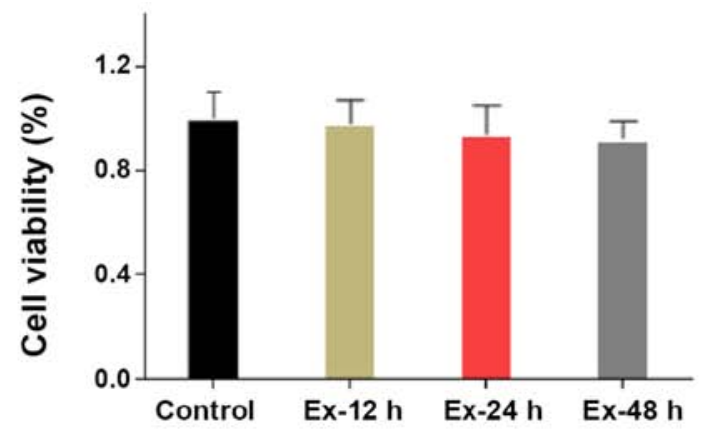

B

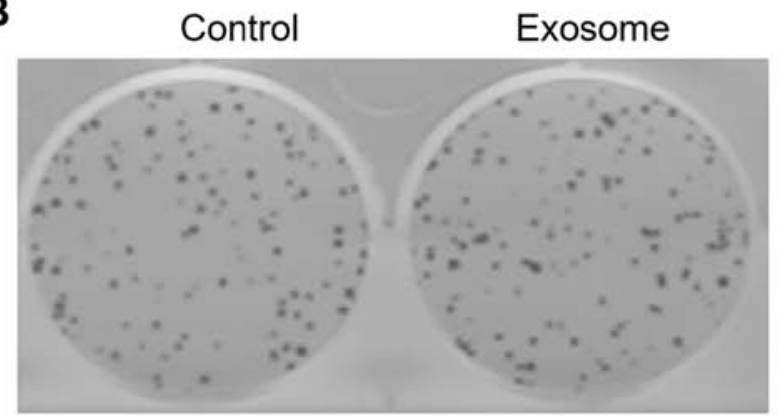

C

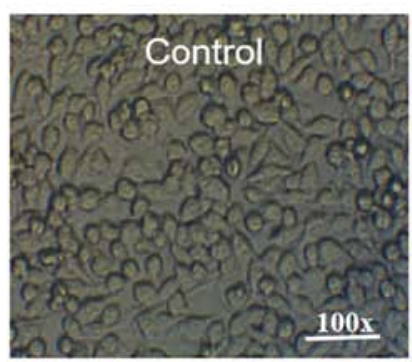

D

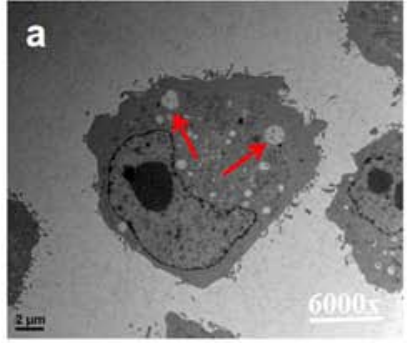

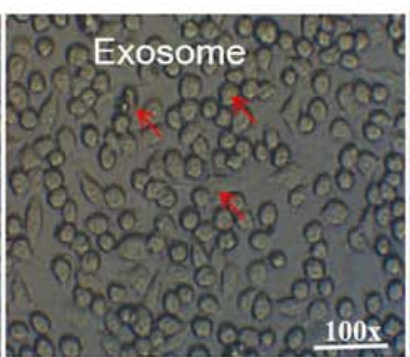

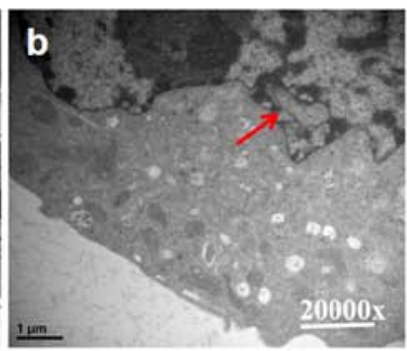

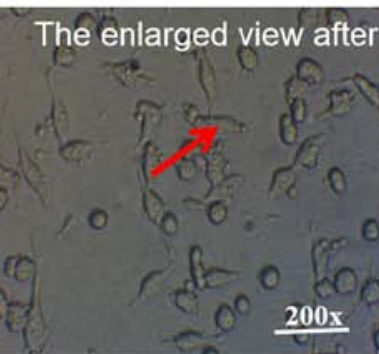

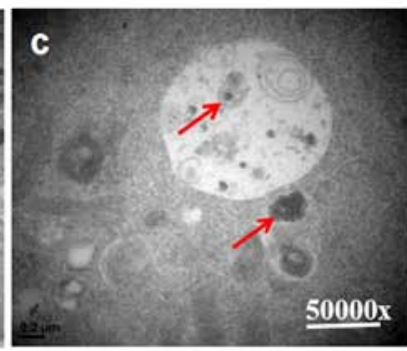

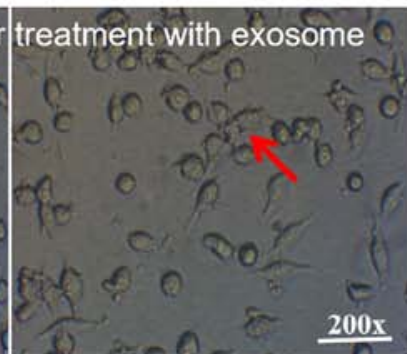

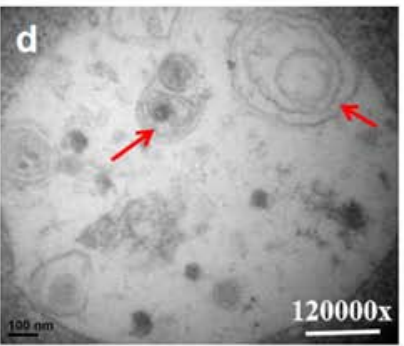

Figure 4. Microglia BV-2 cell autophagy induced by exosomes from bone marrow-derived neural progenitor cells does not affect growth and proliferation. Influence of exosomes on microglial (A) cell viability and (B) colony formation. Autophagic vacuolization (indicated by red arrows) in microglial BV-2 cells treated with exosomes were observed under (C) a light microscope and (D) a transmission electron microscope. The figure below indicates high-power micrographs following the addition of high-concentration exosomes $(5 \mu 1)$. The red arrow indicates the autophagy vesicles.

The potential process of endoplasmic reticulum stress was examined further. As presented in Fig. 5B, after treatment with exosomes, the intracellular $\mathrm{Ca}^{2+}$ level in BV2 cells significantly increased compared with controls. The potential interaction between miR-32-3p and the DAB2IP protein was examined further using luciferase reporter gene assays. As shown in Fig. 5C, miR-32 could bind DAB2IP by directly targeting 3'-UTR, to regulate the expression of DAB2IP mRNA.

\section{Discussion}

A number of studies have demonstrated the important role of microglia autophagy in brain injury, including cranial nerve inflammation, cerebral ischemia and cerebral hypoxia (28-30). Clinical stem cells transplantation frequently fails and does not result in tissue repair (31). It is therefore important to investigate the effect of microglia autophagy in this process. Observation and study on this series of problems will be helpful in exploring future clinical applications regarding cell transplantation. Microglia autophagy serve an important role in the differentiation, survival and homeostasis maintenance of transplanted stem cells (43-46). Previous studies have demonstrated that bone marrow-derived neural progenitor cells can differentiate into neurons and their transplantation in vivo can effectively promote the motor function of rats following brain injury (25-27).

Microglial cell autophagy has also been found in the process of bone marrow-derived neural progenitor cell transplantation during the treatment of brain nerve injury in SD mice in another previous study (47). Investigating the relationship and mechanism between microglia autophagy and the survival and differentiation of neural stem cells are of significance for targeting microglia-associated inflammation, promoting the survival of transplanted neural stem cells in damaged tissues and improving their ability to repair tissues.

The number of studies into the role of exosomes on biological processes is increasing where their importance is gradually being revealed $(48,49)$. However, since the extraction yield of exosomes reported in existing studies has generally been low, the specific molecular mechanism of exosome involvement in intercellular communication remains unclear (50).

Therefore, using informationobtainedfrom previous studies, the present study extracted exosomes of high-yield $(51,52)$ and high purity from bone marrow-derived neural progenitor cells. The molecular mechanism of the effects of autophagy on the relationship between bone marrow-derived neural progenitor cells and microglia was subsequently analyzed by sequencing and western blotting. The pathway of microglia 
A

Control EX-L Ex-H

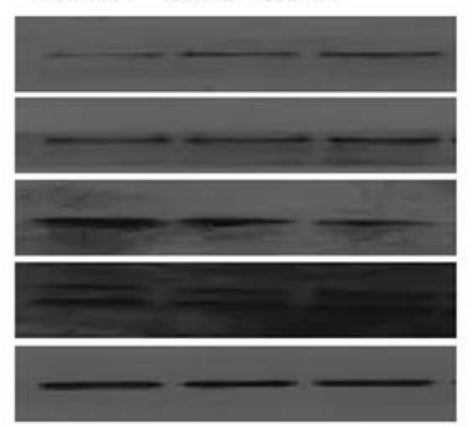

DAB2IP

Beclin1

P62

LC3

$\beta$-actin

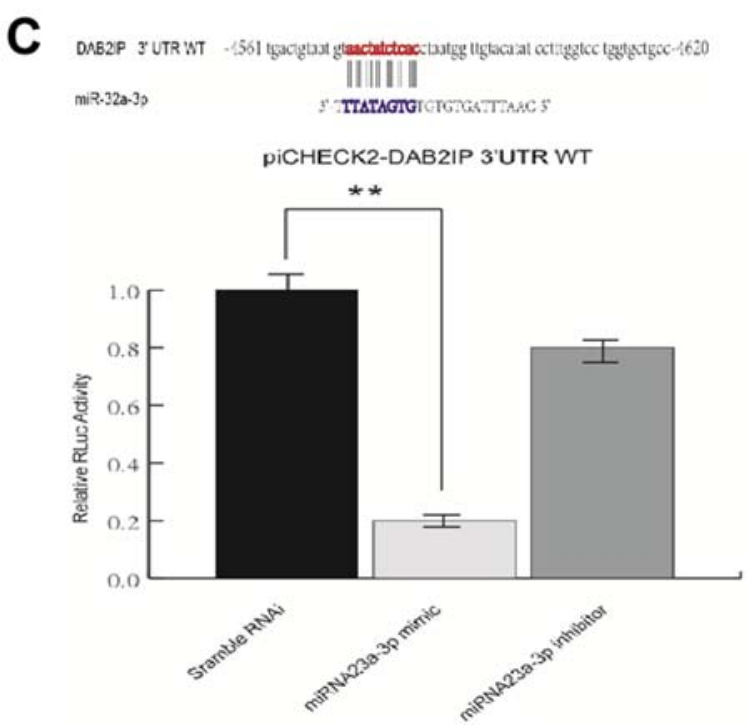

B

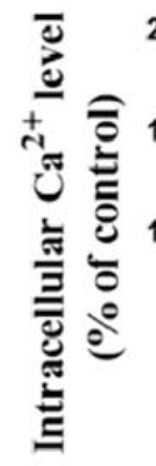

DABZIP ऊUTRBAH mR-32a-30

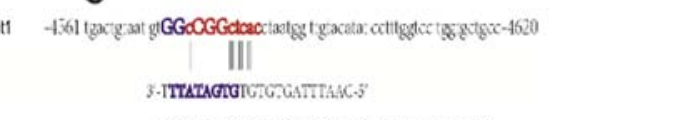

PICHECK2-DAB2IP 3'UTR Mut1

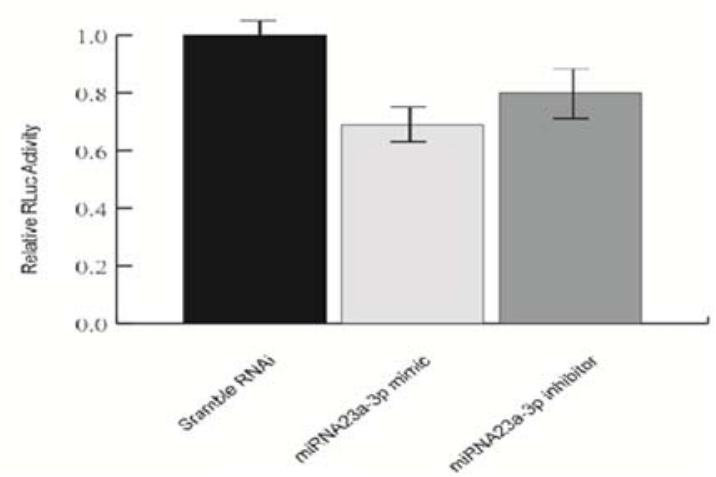

Figure 5. miR-32 binds DAB2IP by directly targeting the 3'-UTR to induce autophagy in microglial cells. (A) The protein expression of DAB2IP, Beclin1, p62 and LC3 were measured via western blotting, where $\beta$-actin was used as an internal control. (B) The intracellular Ca ${ }^{2+}$ level in microglial BV-2 cells was measured before and after exosome treatment. (C) Luciferase activity was performed to test the binding of miR-32 and DAB2IP. 293T cells were co-transfected with either miR-32 mimic or inhibitor and pmi-DAB2IP-3'-UTR-wt or pmiR-DAB2IP-3'-mut. ${ }^{* *} \mathrm{P}<0.0$ vs. control. miR, microRNA; 3'UTR, 3'untranslated region; DAB2IP, disabled homolog 2-interacting protein; LC3, light chain 3; Ex, exosome.

autophagy that was affected by exosome miRNA was then verified, where a potential molecular mechanism of action was proposed. Results of present study provided a basic theoretical basis for an in-depth study on the clinical application of RNA molecules in exosomes secreted by bone marrow-derived neural progenitor cells.

Among the 758 miRNAs detected in the exosomes of bone marrow-derived neural progenitor cells, the top 20 miRNAs were selected according to detection abundance. Their type name, the extent of probe correspondence between original and normalized data, and the active sequence structure information were obtained. Combining bioinformatics analysis and literature reports, four potential miRNAs (rno-miR-32-3p, rno-miR-211-3p, rno-miR-188-5p and rno-miR-465-5p), which have been reported to serve a role in exosome-induced microglia autophagy, were identified $(53,54)$. Using RT-qPCR, differences in the relative expression of these four potential target molecules in microglia in the presence and absence of exosomes of bone marrow-derived neural progenitor cells was investigated further. Following the addition of exosomes from bone marrow-derived neural progenitor cells, all four potential target miRNAs exhibited significantly increased expressions in microglial cells, where the expression of miR-32-3p, which is located in the 14th intron of the gene C9orf5, was found to be the highest, suggesting that it is a potential target molecule. Previous studies on the biological effects of miR-32 have mainly concentrated on tumors, viral replication and androgen regulation, which demonstrated that upon miR-32 overexpression, growth of the androgen-dependent prostate cancer cell line LNCaP was promoted. miR-32 has also been found to reduce apoptosis by directly regulating the expression of the BTG2 gene (55). Upregulation of miR-32 has been reported to inhibit the expression of apoptosis-inducing protein phosphoinositide-3-kinase interacting protein 1 and regulate the Ser/Thr protein kinase mitogen-activated protein kinase kinase, thus serving an important role in a variety of different signal transduction pathways (56). miR-32 serves a regulatory role in a number of physiological processes, including cell growth, differentiation, inflammation, apoptosis, vascular endothelial cell proliferation and neovascularization $(57,58)$. However, the role of miR-32 in microglial growth, proliferation and apoptosis remains poorly understood.

In the present study, molecular and cell biology techniques revealed that exosomes from bone marrow-derived neural 
progenitor cells exerted no significant effects on the growth and proliferation of microglia. Notably, following the addition of exosomes from bone marrow-derived neural progenitor cells, microglia began to develop autophagy, with typical autophagy features (59) observed under light and transmission electron microscopy. The results suggested that exosomes from bone marrow-derived neural progenitor cells can induce microglia autophagy without affecting the growth and proliferation of microglia.

Western blot and luciferase reporter gene assays were performed to validate the potential targets of the miR-32-3p associated regulatory mechanism. Following the addition of exosomes from bone marrow-derived neural progenitor cells, DAB2IP protein expression in microglia was found to be upregulated. The expression of Beclin1, which has been recently determined to be involved in the regulation of autophagy (60), was also found to be upregulated.

These results suggested that autophagy in microglia may be associated with miR-32-3p. In this process, miR-32-3p may be produced by the introduction of exosomes from bone marrow-derived neural progenitor cells. During the induction of autophagy in microglia, the marker protein p62 was degraded in the current study, whilst that of the LC3 protein shear band was increased, suggesting that the conditions for cellular stress to cause the endoplasmic reticulum to initiate autophagy.

The present study also examined the underlying process of endoplasmic reticulum stress. Following the addition of exosomes from bone marrow-derived neural progenitor cells, microglial intracellular calcium concentrations were increased to slightly increased. This suggested that the entry of exogenous signals resulted in the induction of endoplasmic reticulum stress in microglial cells, consistent with the degradation of p62 found in western blotting. Combining these experimental results, the mechanism underlying microglia autophagy induced by the exosomes of bone marrow-derived neural progenitor cells was hypothesized. First, miR-32-3p present in the exosomes secreted by bone marrow-derived neural progenitor cells enter into microglia, where they specifically bind to the DAB2IP to affect its expression. Then, the increase in DAB2IP protein expression in turn promotes the expression of the autophagy-inducing protein Beclin1 and enhances the stress response in microglia. At the same time, the endoplasmic reticulum initiates the stress response mechanism, increasing the intracellular calcium concentration (43) and causing p62 degradation, LC3 cleavage and the formation of cell autophagosomes. In this process, miR-32-3p was found to be a potential target molecule, whilst DAB2IP protein was a potential target protein. Briefly, bone marrow stromal cells (MSCs) are potentially useful for the treatment of a number of brain injury diseases due to their abundant supply. An increasing number of studies have reported their prospective functions and applications $(9,12-17)$. In the present study, 758 miRNAs were detected in exosomes of MSCs using Agilent miRNA chip technology, where rno-miR-32-3p, rno-miR-211-3p, rno-miR-188-5p and rno-miR-465-5p were first found in the exosomes of MSCs.

Since microglia autophagy serves an important role in conditions associated with brain injury, including cranial nerve inflammation, cerebral ischemia and cerebral hypoxia, the results of the present study provided a theoretical reference for studies into brain injury treatment based on neural stem cell transplantation. In addition, the present study provided certain theoretical basis for cell survival and differentiation following transplantation of bone marrow-derived neural progenitor cells, in addition to theoretical and experimental support for future clinical cell transplantation. However, there are some limitations to the present study. For example, it only focused on the biological effects of exosomes from bone marrow-derived neural progenitor cells on microglia, instead of the effects of microglial metabolism. In addition, among the plethora of miRNAs found in the exosome, only 4 potential molecules were studied by bioinformatics analysis and the role of the remaining miRNAs on microglial autophagy cannot be ruled out. The present study only investigated the binding of miR-32-3p to DAB2IP instead of investigating its potential role further, which are the key issues that need to be addressed in the future.

\section{Acknowledgements}

Not applicable.

\section{Funding}

The present study was supported by National Natural Science Foundation of China (NNSFC; grant no. 81871842), the Guangdong Medical Research Fund Project (grant no. A2018510) and the Guangdong Science and Technology Program (grant no. 2016A020214014).

\section{Availability of data and materials}

The datasets used and/or analyzed during the current study are available from the corresponding author on reasonable request.

\section{Authors' contributions}

FYY, MXZ, MSZ and JYO designed and directed the experiments. FYY, MXZ, YHS, WFB and MHL performed the experiments. FYY, WFB and MSZ wrote the manuscript. All authors read and approved the final manuscript.

\section{Ethics approval and consent to participate}

The present study was approved by the Ethics Committee of Guangdong Provincial People's Hospital (Certificate no. GDR EC2018042A).

\section{Patient consent for publication}

Not applicable.

\section{Competing interests}

The authors declare that they have no competing interests.

\section{References}

1. Khan AR, Yang XY, Fu MF and Zhai GX: Recent progress of drug nanoformulations targeting to brain. J Controlled Release 291: 37-64, 2018. 
2. Hakes AE and Brand AH: Neural stem cell dynamics: The development of brain tumours. Curr Opin Cell Biol 60: 131-138, 2019.

3. Chrostek MR, Fellows EG, Crane AT, Grande AW and Walter C: Low efficacy of stem cell-based therapies for stroke. Brain Res 1722: 146362, 2019.

4. Grochowski C, Radzikowska E and Maciejewski R: Neural stem cells therapy-Brief review. Clin Neurol Neurosurg 173: 8-14, 2018.

5. Huang L and Zhang LB: Neural stem cell therapies and hypoxic-ischemic brain injury. Prog Neurobiol 173: 1-17, 2019.

6. Kochanek PM, Jackson TC, Ferguson NM, Carlson SW, Simon DW, Brockman EC, Ji J, Bayır H, Poloyac SM, Wagner AK, et al: Emerging therapies in traumatic brain injury. Semin Neurol 35: 83-100, 2015.

7. Ogawa Y, Sawamoto K, Miyata T, Miyao S, Watanabe M, Nakamura M, Bregman BS, Koike M, Uchiyama Y, Toyama Y and Okano H: Transplantation of in vitro-expanded fetal neural progenitor cells results in neurogenesis and functional recovery after spinal cord contusion injury in adult rats. J Neurosci Res 69: 925-933, 2002.

8. Volpe G, Bernstock JD, Peruzzotti-Jametti L and Pluchino S: Modulation of host immune responses following non-hematopoietic stem cell transplantation: Translational implications in progressive multiple sclerosis. J Neuroimmunol 331 : $11-27,2019$

9. Gupta N, Henry RG, Kang SM, Strober J, Lim DA, Ryan T, Perry R, Farrell J, Ulman M, Rajalingam R, et al: Long-term safety, immunologic response, and imaging outcomes following neural stem cell transplantation for pelizaeus-merzbacher disease. Stem Cell Rep 13: 254-261, 2019.

10. Wang YH, Chen JA, Zhou J, Nong F, Lv JH and Liu J: Reduced inflammatory cell recruitment and tissue damage in spinal cord injury by acellular spinal cord scaffold seeded with mesenchymal stem cells. Exp Ther Med 13: 203-207, 2017.

11. Adams KV and Morshead CM: Neural stem cell heterogeneity in the mammalian forebrain. Prog Neurobiol 170: 2-36, 2018.

12. Ning Y, Wang X, Zhang P, Liu A, Qi X, Liu M and Guo X: Dietary exosome-miR-23b may be a novel therapeutic measure for preventing Kashin-Beck disease. Exp Ther Med 15: 3680-3686, 2018.

13. Yang Y, Bucan V, Baehre H, Ohe JVD, Otte A and Hass R: Acquisition of new tumor cell properties by MSC-derived exosomes. Int J Oncol 47: 244-252, 2015

14. Lee KS, Choi JS and Cho YW: Reprogramming of cancer stem cells into non-tumorigenic cells using stem cell exosomes for cancer therapy. Biochem Biophys Res Commun 512: 511-516, 2019.

15. Li L, Liu S, Xu Y, Zhang A, Jiang J, Tan W, Xing J, Feng G, Liu H, Huo F, et al: Human umbilical cord-derived mesenchymal stem cells downregulate inflammatory responses by shifting the Treg/Th17 profile in experimental colitis. Pharmacology 92: 257-264, 2013

16. Pan D, Chang X, Xu M, Zhang M, Zhang S, Wang Y, Luo X, $\mathrm{Xu}$ J, Yang X and Sun X: UMSC-derived exosomes promote retinal ganglion cells survival in a rat model of optic nerve crush. J Chem Neuroanat 96: 134-139, 2019.

17. Cho JA, Park HP, Lim EH and Lee KW: Exosomes from breast cancer cells can convert adipose tissue-derived mesenchymal stem cells into myofibroblast-like cells. Int J Oncol 40: 130-138, 2011.

18. Pankiv S, Alemu EA, Brech A, Brech A, Bruun JA, Lamark T Overvatn A, Bjørkøy G and Johansen T: FYCO1 is a Rab7 effector that binds to LC3 and PI3P to mediate microtubule plus end-directed vesicle transport. Cell Biol 188: 253-269, 2010.

19. Demarco RS, Uyemura BS and Jones DL: Egfr signaling stimulates autophagy to regulate stem cell maintenance and lipid homeostasis in the drosophila testis. Cell Rep 30: 1101-1116, 2020.

20. Mizushima N, Yoshimori $\mathrm{T}$ and Levine B: Methods in mammalian autophagy research. Cell 140: 313-326, 2010.

21. Polazzi E and Monti B: Microglia and neuroprotection: From in vitrostudies to therapeutic applications. Prog Neurobiol 92: 293-315, 2010

22. Hu X, Leak RK, Shi Y, Suenaga J, Gao Y, Zheng P and Chen J: Microglial and macrophage polarization-new prospects for brain repair. Nat Rev Neurol 11: 56-64, 2015

23. Li D, Huang S, Yin Z, Zhu J, Ge X, Han Z, Tan J, Zhang S, Zhao J, Chen F, et al: Increases in miR-124-3p in microglial exosomes confer neuroprotective effects by targeting fip200-mediated neuronal autophagy following traumatic brain injury. Neurochem Res 44: 1903-1923, 2019.
24. Wang Y, Zhou K, Li T, Xu Y, Xie C, Sun Y,Zhang Y, Rodriguez J, Blomgren $\mathrm{K}$ and Zhu C: Inhibition of autophagy prevents irradiation-induced neural stem and progenitor cell death in the juvenile mouse brain. Cell Death Dis 8: e2694, 2017.

25. Bai WF, Feng Y, Huang $\mathrm{H}$ and Zhang MS: Fifty-hertz electromagnetic fields facilitate the induction of rat bone mesenchymal stromal cells to differentiate into functional neurons. Cytotherapy 15: 961-970, 2013

26. Bai WF, Xu WC, Zhu HX, Huang H, Wu B and Zhang MS: Efficacy of $50 \mathrm{~Hz}$ electromagnetic fields on human epidermal stem cell transplantation seeded in collagen sponge scaffolds for wound healing in a murine model. Bioelectromagnetics 38 : 204-212, 2017.

27. Bai WF, Zhang MS, Huang H, Zhu HX and Xu WC: Effects of $50 \mathrm{~Hz}$ electromagnetic fields on human epidermal stem cells cultured on collagen sponge scaffolds. Int J Radiat Biol 88: 523-530, 2012

28. He HY, Ren L, Guo T and Deng YH: Neuronal autophagy aggravates microglial inflammatory injury by downregulating CX3CL1/fractalkine after ischemic stroke. Neural Regen Res 14 280-288, 2019

29. Bie M, Lv Y, Ren C, Xing F, Cui Q, Xiao J and So KF: Lycium barbarum polysaccharide improves bipolar pulse current-induced microglia cell injury through modulating autophagy. Cell Transplant 24: 419-28, 2015.

30. Wang XT, Ma J, Fu Q, Zhu L, Zhang ZL, Zhang F, Lu N and Chen AM: Role of hypoxia-inducible factor- $1 \alpha$ in autophagic cell death in microglial cells induced by hypoxia. Mol Med Rep 15: 2097-2105, 2017

31. Rajendran JC, Bose and Robert F: Mattrey. Accomplishments and challenges in stem cell imaging in vivo. Drug Discov Today 24: 492-504, 2019.

32. Li XP, Wang X, Bai LM, Zhao P and Zhang MS: Exposure to $50 \mathrm{~Hz}$ electromagnetic fields enhances hair follicle regrowth in C57BL/6 mice. Exp Biol Med (Maywood) 244: 389-394, 2019.

33. Livak KJ and Schmittgen TD: Analysis of relative gene expression data using real-time quantitative PCR and the 2(-Delta Delta $\mathrm{C}(\mathrm{T})$ ) method. Methods 25: 402-408, 2001

34. Yong TY, Zhang XZ, Bie NB, Zang HZ, Zang XH, Li FL, Hakeem AH, Hu JH, Gan LG, Santos HAS and Yang XY: Tumor exosome-based nanoparticles are efficient drug carriers for chemotherapy. Nature Comm 10: 3838, 2019.

35. Kyei B, Li L, Yang L, Zhan SY and Zhang HP CDR1as/miRNAs-related regulatory mechanisms in muscle development and diseases. Gene 730: 144315, 2020.

36. Kashyap D and Kaur H: Cell-free miRNAs as non-invasive biomarkers in breast cancer: Significance in early diagnosis and metastasis prediction. Life Sci 2461: 7417, 2020.

37. Ozeki N, Hase N, Hiyama T, Yamaguchi H, Kawai-Asano R, Nakata K and Mogi M: MicroRNA-211 and autophagy-related gene 14 signaling regulate osteoblast-like cell differentiation of human induced pluripotent stem cells. Exp Cell Res 352: 63-74, 2017.

38. Meng F, Zhang S, Song R, Liu Y, Wang J, Liang Y, Wang J, Han J, Song X, Lu Z, et al: NCAPG2 overexpression promotes hepatocellular carcinoma proliferation and metastasis through activating the STAT3 and $\mathrm{NF}-\kappa \mathrm{B} / \mathrm{miR}-188-3 \mathrm{p}$ pathways EBioMedicine 44: 237-249, 2019

39. Liao H, Xiao Y, Hu Y, Xiao Y, Yin Z and Liu L: MicroRNA-32 induces radioresistance by targeting DAB2IP and regulating autophagy in prostate cancer cells. Oncol Lett 10: 2055-2062, 2015.

40. Wang D, Zeng T, Lin Z, Yan L, Wang F, Tang L, Wang L, Tang D, Chen $\mathrm{P}$ and Yang $\mathrm{M}$ : Long non-coding RNA SNHG5 regulates chemotherapy resistance through the miR-32/DNAJB9 axis in acute myeloid leukemia. Biomed Pharmacother 123: 109802, 2020.

41. Liu KX, Chen GP, Lin PL, Huang JC, Lin X, Qi JC and Lin QC: Detection and analysis of apoptosis- and autophagy-related miRNAs of mouse vascular endothelial cells in chronic intermittent hypoxia model. Life Sci 193: 194-199, 2018.

42. Yu L, Tumati V, Tseng SF, Hsu FM, Kim DN, Hong D, Hsieh JT, Jacobs C, Kapur P and Saha D: DAB2IP regulates autophagy in prostate cancer in response to combined treatment of radiation and a DNA-PKcs inhibitor. Neoplasia 14: 1203-1212, 2012.

43. Rong Y, Liu W, Wang J, Fan J, Luo Y, Li L, Kong F, Chen J, Tang $\mathrm{P}$ and Cai W: Neural stem cell-derived small extracellular vesicles attenuate apoptosis and neuroinflammation after traumatic spinal cord injury by activating autophagy. Cell Death Dis 10: 340, 2019. 
44. Kang I, Lee BC, Lee JY, Kim JJ, Sung EA, Lee SE, Shin N, Choi SW, Seo Y, Kim HS and Kang KS: Stem cell-secreted 14,15- epoxyeicosatrienoic acid rescues cholesterol homeostasis and autophagic flux in Niemann-pick-type C disease. Exp Mol Med 50: 1-14, 2018.

45. Sung K and Jimenez-Sanchez M: Autophagy in astrocytes and its implications in neurodegeneration. J Mol Biol 432: 2605-2621, 2020.

46. Oliveira MC, Elias JB, Moraes DA, Simões BP, Rodrigues M, Ribeiro AAF, Piron-Ruiz L, Ruiz MA and Hamerschlak N: A review of hematopoietic stem cell transplantation for autoimmune diseases: Multiple sclerosis, systemic sclerosis and Crohn's disease. Hematol Transfus Cell Ther: 30032-30038, 2020.

47. Bai WF: Bone marrow derived neural progenitor cells differentiate into neurons and promote neurogenesis of brain injury rats (unpublished $\mathrm{PhD}$ thesis). Jinan University, 2017.

48. Rahmati S, Shojaei F, Shojaeian A, Rezakhani L and Dehkordi MB: An overview of current knowledge in biological functions and potential theragnostic applications of exosomes. Chem Phys Lipids 226: 104836, 2020.

49. Shi ZY, Yang XX, Malichewe CY, Li YS and Guo XL: Exosomal microRNAs-mediated intercellular communication and exosome-based cancer treatment. Int J Biol Macromol 158: 530-541, 2020

50. Su WT, Li HJ, Chen WW and Qin JH: Microfluidic strategies for label-free exosomes isolation and analysis. TrAC Trend Anal Chem 118: 686-698, 2019.

51. Riazifar M, Pone EJ, Lötvall J and Zhao W: Stem cell extracellular vesicles: Extended messages of regeneration. Annu Rev Pharmacol Toxicol 57: 125-154, 2017

52. Reyes-Ruiz JM, Osuna-Ramos JF, Jesús-González LAD, Hurtado-Monzón AM, Farfan-Morales CN, Cervantes-Salazar M, Bolaños J, Cigarroa-Mayorga OE, Martín-Martínez ES, Medina F, et al: Isolation and characterization of exosomes released from mosquito cells infected with dengue virus. Virus Res 266: 1-14, 2019.

53. Liang PH, Mao L, Zhang SH, Guo X, Liu G, Wang L, Hou J, Zheng Y and Luo X: Identification and molecular characterization of exosome-like vesicles derived from the Taenia asiatica adult worm. Acta Trop 198: 105036, 2019.
54. Li D, Huang S, Zhu J, Hu T, Han Z, Zhang S, Zhao J, Chen F and Lei P: Exosomes from miR-21-5p-increased neurons play a role in neuroprotection by suppressing Rab11a-mediated neuronal autophagy in vitro after traumatic brain injury. Med Sci Monit 25: 1871-1885, 2019.

55. Xia W, Shi R, Zheng WL and Ma WL: Lack of association between cytotoxic T-lymphocyte antigen-4 -318C/T polymorphism and cancer risk: A meta-analysis of case-control studies. Technol Cancer Res Treat 12: 565-574, 2013.

56. Ng R, Hussain NA, Zhang Q, Chang C, Li H, Fu Y, Cao L, Han W, Stunkel $\mathrm{W}$ and $\mathrm{Xu}$ F: miRNA-32 drives brown fat thermogenesis and trans-activates subcutaneous white fat browning in mice. Cell Rep 19: 1229-1246, 2017.

57. Jiang M, Wang H, Jin M, Yang X, Ji H, Jiang Y, Zhang H, Wu F, Wu G, Lai X, et al: Exosomes from MiR-30d-5p-ADSCs reverse acute ischemic stroke-induced, autophagy-mediated brain injury by promoting M2 microglial/macrophage polarization. Cell Physiol Biochem 47: 864-878, 2018.

58. Chappell WH, Abrams SL, Lertpiriyapong K, Fitzgerald TL, Martelli AM, Cocco L, Rakus D, Gizak A, Terrian D, Steelman LS and McCubrey JA: Novel roles of androgen receptor, epidermal growth factor receptor, TP53, regulatory RNAs, NF-kappa-B, chromosomal translocations, neutrophil associated gelatinase, and matrix metalloproteinase-9 in prostate cancer and prostate cancer stem cells. Adv Biol Regul 60: 64-87, 2016.

59. Li X, Wang Y, Xiong Y, Wu J, Ding H, Chen X, Lan L and Zhang H: Galangin induces autophagy via deacetylation of LC3 by SIRT1 in HepG2 cells. Sci Rep 6: 30496, 2016.

60. Politano G, Logrand F, Brancaccio M and Di Carlo S: In-silico cardiac aging regulatory model including microRNA post-transcriptional regulation. Methods 124: 57-68,2017. International (CC BY-NC-ND 4.0) License. 